\title{
Emerging role of Garcinol, the antioxidant chalcone from Garcinia indica Choisy and its synthetic analogs Subhash Padhye ${ }^{1,2}$, Aamir Ahmad ${ }^{1}$, Nikhil Oswal ${ }^{3}$ and Fazlul H Sarkar*1
}

Address: ${ }^{1}$ Department of Pathology, Barbara Ann Karmanos Cancer Center and Wayne State University School of Medicine, Detroit, MI 48201, USA, ${ }^{2}$ D.Y. Patil University of Pharmaceutical Sciences and Research, Pune 411018, India and ${ }^{3}$ D.Y. Patil Institute of Pharmaceutical Sciences and Research, Pune 411018, India

Email: Subhash Padhye - sbpadhye@hotmail.com; Aamir Ahmad - ahmada@karmanos.org; Nikhil Oswal - oswalnikhil_303@rediffmail.com; Fazlul H Sarkar* - fsarkar@med.wayne.edu

* Corresponding author

Published: 2 September 2009

Journal of Hematology \& Oncology 2009, 2:38 doi:10.1 I86/1756-8722-2-38

This article is available from: http://www.jhoonline.org/content/2/1/38

(c) 2009 Padhye et al; licensee BioMed Central Ltd.

This is an Open Access article distributed under the terms of the Creative Commons Attribution License (http://creativecommons.org/licenses/by/2.0), which permits unrestricted use, distribution, and reproduction in any medium, provided the original work is properly cited.
Received: I August 2009

Accepted: 2 September 2009

\begin{abstract}
Garcinol, harvested from Garcinia indica, has traditionally been used in tropical regions and appreciated for centuries; however its biological properties are only beginning to be elucidated. There is ample data to suggest potent antioxidant properties of this compound which have been used to explain most of its observed biological activities. However, emerging evidence suggests that garcinol could be useful as an anti-cancer agent, and it is increasingly being realized that garcinol is a pleiotropic agent capable of modulating key regulatory cell signaling pathways. Here we have summarized the progress of our current research knowledge on garcinol and its observed biological activities. We have also provided an explanation of observed properties based on its chemical structure and provided an insight into the structure and properties of chalcones, the precursors of garcinol. The available data is promising but more detailed investigations into the various properties of this compound, particularly its anti-cancer activity are urgently needed, and it is our hope that this review will stimulate further research for elucidating and appreciating the value of this nature's wonder agent.
\end{abstract}

\section{Introduction}

It is difficult to imagine that the pink sweet smelling drink that is served to the world travelers spending summer holidays on the beautiful beaches of Goa in India, upon their arrival at the hotel, could one day end up on the laboratory tables of Cancer Institutes around the world. The welcome drink happens to be made from the syrup formulated from the fruits locally known as 'Kokum' which is steeped in sugar syrup to make a drink which is used to avoid skin damages and allergies from the sun and tropical climate. The plant grows extensively on the western coast of India and is known by various names across India including Bindin, Biran, Bhirand, Bhinda, Katambi,
Panarpuli, Ratamba or Amsool. In English language, it is also known by various names such as Mangosteen, wild Mangosteen, or Red Mango. According to botanical classification the tree is classified as Garcinia indica (Family: Clusiaceae; Genus: Garcinia)which has many culinary, pharmaceutical and industrial uses. The genus Garcinia includes some 200 species found in the tropics, especially Asia and Africa. Out of 35 species found in India, 17 are endemic. Of these, seven are endemic to the region of Western Ghats including the state of Goa, six in the Andaman and Nicobar Islands and four in the North-Eastern region of India. 
The Garcinia indica seed contains 23-26\% oil, which remains solid at room temperature and is used in the preparation of chocolates, medicines and cosmetics. It is used as a slightly bitter spice in recipes from the state of Maharashtra in India and as a souring agent and a substitute for tamarind paste in Indian curries. Recently, some industries have started extracting hydroxycitric acid (HCA) from the rind of the fruit which is an important constituent used as a hypocholesterolaemic agent. HCA is also a potential anti-obesity agent [1]. It suppresses fatty acid synthesis, lipogenesis, and food intake, and thus induces weight loss. Kokum Butter is an excellent emollient used by the cosmetic industry for preparations of lotions, creams, lip-balms and soaps. It has relatively high melting point and is considered as one of the most stable exotic butter which dose not need any refrigeration. It is extracted from the Kokum seed and is supposed to reduce degeneration of the skin cells and restore elasticity. The extract of the plant finds place in the specialty cuisine of West Coast of India as an appetizer while decoction of the bark is used for treating paralysis. The antioxidant activity of aqueous extract of the plant has been reported, which is higher than other reported spices and fruits thus promoting its use in cooking, home remedies and as a soft drink [2]. Garcinia indica extract has also been shown to inhibit Aspergillus flavus and aflatoxin $\mathrm{B}_{1}$ production thereby demonstrating its putative bio-preservative properties [3]. Addition of Garcinia extract to fresh skipjack (dark muscle fish) has been demonstrated to prevent histamine formation by lowering the $\mathrm{pH}$ to 3.2-3.6 [4]. Since histamine is known to give rise to allergic reactions, Garcinia extracts can potentially find use in anti-allergy medications.

\section{Isolation and characterization of chemical constituents}

Garcinia indica extracts, especially from its rind, are rich in polyisoprenylated benzophenone derivatives such as Garcinol and its colorless isomer, Isogarcinol. The rind also contains hydroxycitric acid (HCA), hydroxycitric acid lactone, citric acid and oxalic acid. The structures of these compounds are shown in Figure 1. The fruit also contains other compounds including malic acid, polyphenols, carbohydrates, anthocyanin, pigments and ascorbic acid. Garcinol shows strong antioxidant activity since it contains both phenolic hydroxyl groups as well as a $\beta$-diketone moiety, and in this respect it resembles with the wellknown antioxidant of plant origin, viz. Curcumin [5] (Figure 1).

A reverse-phase high-performance liquid chromatographic method has been developed by Chattopadhyay and Kumar for qualitative and quantitative analysis of Xanthochymol and Isoxanthochymol in the fruit rinds, leaves and seed pericarps of Garcinia indica using PDA

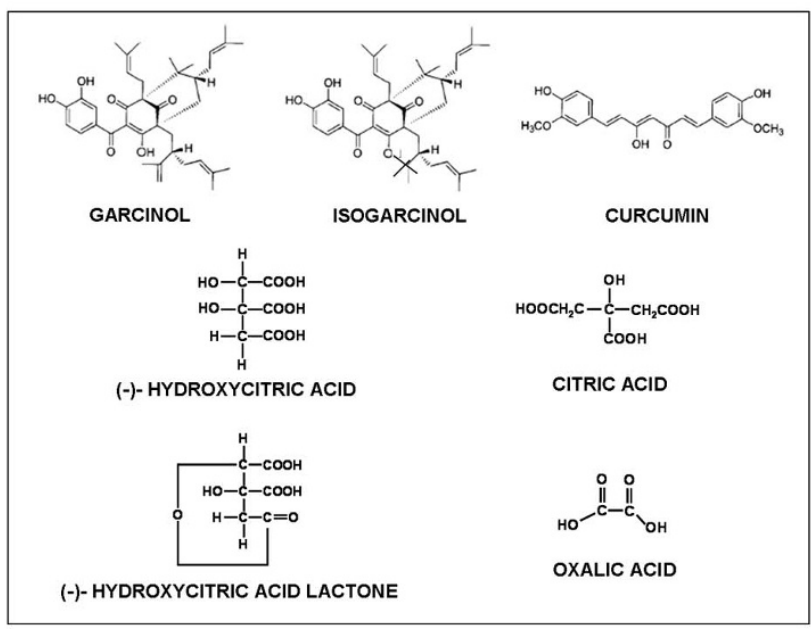

\section{Figure I \\ Structure of Garcinol, Curcumin and compounds extracted from Garcinia indica.}

detector and electrospray ionization mass spectra. Absorption at $276 \mathrm{~nm}$ was chosen as the measuring wavelength at which resolution of both compounds could be obtained [6-9]. More recently, these workers have developed a rapid, sensitive and simple reverse-phase high-performance liquid chromatography-electrospray ionization mass spectrometric method for the identification and quantification of two isomeric polyisoprenylated benzophenones, isoxanthochymol and camboginol, in the extracts of the stem bark, seeds and seed pericarps of Garcinia indica and in the fruit rinds of Garcinia cambogia [10]. The major organic acid in leaves and rinds of Garcinia indica is reported to be (-)-hydroxycitric acid, present to the extent of 4.1-4.6 and 10.3-12.7\% respectively, as determined by HPLC $[11,12]$.

Garcinol, with a molecular weight of 602, is the active principle of Garcinia indica, which is crystallized out as yellow needles $(1.5 \%)$ from the hexane extract of the fruit rind. The molecular formula and the absorption spectral data indicate that the compound is possibly related to the isomeric Xanthochymol and more appropriately, in view of the sign of optical rotation, to Cambogin. The presence of an enolisable 1, 3-diketone system in the molecule is confirmed by the formation of two isomeric trimethyl ethers, hydrolysable to single dimethyl ether with dilute alkali. Alkali degradation of the methyl ether under stronger conditions (20\% ethanolic $\mathrm{KOH}$, reflux) yields veratric acid indicating the presence of a 3,4-dihydroxybenzoyl unit. The UV spectrum of garcinol suggests that the 1,3-diketone system is conjugated to the 3, 4-dihydroxybenzoyl moiety. The IR spectrum of the trimethyl ether shows the presence of a saturated carbonyl group $\left(1727 \mathrm{~cm}^{-1}\right)$ and two $\alpha, \beta$-unsaturated carbonyl groups 
(1668 and $1642 \mathrm{~cm}^{-1}$ ), accounting for all the oxygen atoms.

The PMR spectrum of garcinol in $\mathrm{CDC}_{3}$ shows the presence of two saturated tertiary methyls (singlets at $\delta 1.01$ and 1.17) and seven $=\mathrm{C}^{-\mathrm{CH}_{3}}$ groups (signals at $\delta 1.54$ for two methyls and at 1.60, 1.67, 1.70, 1.74 and 1.84 for one methyl each). It also shows signals for a vinylic methylene ( $\delta 4.38,2 \mathrm{H}$, broad singlet) and three other olefinic protons $(\delta 5.0 \mathrm{~m})$ in addition to three aromatic protons (ABX pattern around $\delta 6.60$ and 6.95) and a hydrogen bonded phenolic hydroxyl at $\delta$ 18.0. The mass spectrum of garcinol is very similar to that of Xanthochymol exhibiting major peaks at $\mathrm{m} / \mathrm{e} 602\left(\mathrm{M}^{+}\right), 465\left(\mathrm{M}^{+}-\mathrm{C}_{10} \mathrm{H}_{17}\right.$, base peak), $341\left(465-\mathrm{C}_{9} \mathrm{H}_{16}\right)$ and 137 (Dihydroxybenzoyl). These features clearly indicate that the structure of garcinol is biogenetically derivable from Maclurin $\left(2,4,6,3^{\prime}, 4^{\prime}\right.$ pentahydroxybenzophenone) and five isoprenyl units $[13,14]$.

\section{Chemistry of garcinol}

The principle antioxidant substance of Garcinia indica and other species is Garcinol (Figure 1) also called as Camboginol, which is a tri-isoprenylated chalcone $[15,16]$. This compound is extracted from the dried fruit rind of the plant. It scavenges 1, 1-diphenyl-2-picrylhydrazyl (DPPH) free radical (3 times more effectively than DL-Rtocopherol), hydroxyl radical (more effectively than DLR-tocopherol), methyl radical, and superoxide anion [17]. Sang et al. have reported the structure of some oxidation products of garcinol and have proposed mechanisms for the formation of these products $[18,19]$. Their results suggest that garcinol can play an important role in the treatment of gastric ulcers caused by the hydroxyl radicals or chronic infection with Helicobacter pylori, which, together with cells from gastric mucous membrane, produces hydroxyl radicals and superoxide anions. Presently, treatment with Clarithromycin antibiotic is the therapy of choice for treating $H$. pylori infection, which, however, suffers from side effects and emergence of rapid resistance $[20,21]$. Garcinol may be a viable alternative to conventional antibiotics. Garcinol shows antibacterial activity against Methicillin-resistant Staphylococcus aureus [22] which is comparable to that of the antibiotic Vancomycin (MIC - 3-12 $\mu \mathrm{g} / \mathrm{mL}$ for garcinol Vs. $6 \mu \mathrm{g} / \mathrm{mL}$ for Vancomycin) [23]. It also inhibits topoisomerases I and II $\left(\mathrm{IC}_{50}=\right.$ 43 and $55 \mu \mathrm{g} / \mathrm{mL}$ respectively) at concentrations comparable to that of Etoposide $\left(\mathrm{IC}_{50}=70 \mu \mathrm{g} / \mathrm{mL}\right.$ for topoisomerases II) [24]. Although this compound has been shown to exhibit therapeutic activity against gram-positive and gram-negative cocci, mycobacteria and fungi, it has been found to be inactive against gram-negative enteric bacilli, yeasts and viruses [25]. Garcinol exerts anti-cholinesterase properties towards acetyl cholineste- rase (AChE) and butylcholinesterase. The $\mathrm{IC}_{50}$ value of garcinol $(0.66 \mu \mathrm{M})$ against AChE is comparable to that of the reference compound Galanthamine $(0.50 \mu \mathrm{M})$ [26].

Isogarcinol also shows biological activities similar to that of garcinol and has been claimed to be an anti-inflammatory and antitumor compound, a lipase inhibitor, an antiobesity agent as well as an antiulcer agent [18]. Sang et al. have studied the interaction of garcinol with peroxyl radicals generated by thermolysis of the initiator 2, 2'-azobisisobutyronitrile (AIBN) and have succeeded in isolating and characterizing reaction products of garcinol in a homogeneous acetone system. The resulting compounds were found capable of inducing apoptosis in human leukemia HL-60 cells and inhibit NO radical generation as well as LPS-induced iNOS gene expression, respectively $[18,19]$. Garcinol showed good antitumor activity against human leukemia HL-60 cells, being more effective than curcumin, which was used as a reference compounds in these studies. In addition to HL-60 cells, the chemotherapeutic potential of garcinol has been examined on other cell lines as well such as murine macrophage RAW 264.7 cells and cyclin D1-positive cells showing similar results. Additionally garcinol also inhibits histone acetyltransferases (HATs, $\mathrm{IC}_{50}=7 \mu \mathrm{M}$ ) and p300/CPB-associated factor (PCAF, $\left.\mathrm{IC}_{50}=5 \mu \mathrm{M}\right)$, both of which are known to modulate gene expression [27].

\section{Biological activities of garcinol a. Antioxidant Activity}

Garcinol has been shown to possess antioxidant activity in the $\mathrm{H}_{2} \mathrm{O}_{2}-\mathrm{NaOH}-\mathrm{DMSO}$ system as well as the radical scavenging activity against superoxide anion, hydroxyl radical and methyl radical respectively. The emulsified garcinol suppresses superoxide anion to almost same extent as DL- $\alpha$ tocopherol by weight, while it exhibits nearly three times greater free radical scavenging activity against 2, 2, diphenyl-1-picrylhydrazyl (DPPH) radicals than DL- $\alpha$ tocopherol by weight [28]. The following paragraphs describe the known mechanism of antioxidant activity of garcinol.

Hong et al. have investigated possible mechanisms of antioxidant action of garcinol and its derivatives on arachidonic acid metabolism and NO radical synthesis at concentrations $(>1 \mu \mathrm{M})$ that may be achievable under in vivo conditions. The preliminary results indicate that peak plasma and urine plasma concentration levels of garcinol in CD-1 female mice were 12 and $2.7 \mu \mathrm{M}$ respectively, after oral gavage of garcinol (10 mg dose per mouse) [29]. Sang et al. also proposed the antioxidant mechanism of garcinol according to which the compound reacts with peroxyl radicals by a single electron transfer followed by deprotonation of the hydroxyl group from the enolized 1 , 
3-diketone to form a resonance pair. Depending on the position of hydroxyl group (C-3 or C-5) which initiates the reaction, different compounds are formed $[18,19]$.

The neuroprotective effects of garcinol were examined by Liao et al who found that at $5 \mu \mathrm{M}$ concentration it prevented NO radical accumulation in LPS-treated astrocytes and significantly reduced the expression of LPS-induced inflammatory mediators, such as iNOS and COX-2 [30]. These results suggest that the neuroprotective effects of garcinol are associated with its antioxidant nature involving inhibition of iNOS induction in astrocytes. It has been suggested that the compound may be neuroprotective against brain injury through similar mechanism [30]. Yamaguchi et al. studied various pharmacological activities of garcinol including antioxidant activity, chelating activity, free radical scavenging activity and anti-glycation activity. They observed that garcinol exhibited reasonable antioxidant activity in the micellar linoleic acid peroxidation system and exhibited chelating activity at almost the same level as citrates. In a phenazine methosulfate/ NADH-nitro blue tetrazolium system garcinol exhibited superoxide anion scavenging activity and suppressed protein glycation in a bovine serum albumin/fructose system. Thus, the compound may be useful as a glycation inhibitor under specified conditions [17].

\section{b. Anti-inflammatory activity}

Aberrant arachidonic acid metabolism and generation of nitric oxide radicals (NO) have been shown to be involved in inflammation and carcinogenesis [29]. Arachidonic acid is released by phospholipase $A_{2}$ (cPLA2) from membrane phospholipids and is further metabolized by cyclooxygenase (COX), lipooxygenase (LOX) enzymes and Cytochrome P450 pathways. Modulation of arachidonic acid metabolism by inhibiting COX and LOX enzymes has been considered as an effective approach for treating inflammation and for cancer chemoprevention [29]. Garcinol and its derivatives modulate arachidonic acid metabolism by retarding the phosphorylation of cytosolic PLA2 (cPLA $)$ through the inhibition of extracellular ERK1/2 kinase activation and suppression of iNOS expression through modulation of the Janus kinase (JAK)/ STAT-1 signaling pathway. When added prior to LPS, garcinol suppressed NF- $\kappa \mathrm{B}$ activation and COX-2 expression through the interruption of LPS binding to toll-like receptors [29].

The nitric oxide radical moiety is involved in various physiological processes, including vasodilation, inhibition of platelet function, synaptic neurotransmission as well as host defense. The formation of NO radicals from arginine in the biological system is catalyzed by three different types of nitric oxide synthase (NOS) enzymes, viz. endothelial NOS, neuronal NOS and inducible NOS
(iNOS), respectively. The enzyme iNOS is stimulated by inflammatory cytokines for NO production by macrophages and by many other cell types. It has been reported that garcinol inhibits the expression of iNOS and COX-2 in lipopolysaccharide (LPS)-activated macrophages [31]. It was observed that garcinol strongly blocks the LPSinduced activation of eukaryotic transcription factor NF$\kappa \mathrm{B}$ [31]. This inhibition of NF- $\kappa \mathrm{B}$ activation takes place through the suppression of phosphorylation of IкB- $\alpha$ and p38 Mitogen-Activated Protein Kinases (MAPK). Garcinol lowers the LPS-induced increase of intracellular reactive oxygen species (ROS), which contribute to the activation of NF- $\kappa B$ [31].

Recently Koeberle et al. have shown that garcinol significantly interferes with two enzymes that play crucial roles in inflammation and tumorigenesis, viz. 5-lipoxygenase and microsomal prostaglandin PGE $_{2}$ synthase (mPGES)- 1 [32]. In cell-free assays garcinol inhibits the activity of purified 5-lipoxygenase and blocks the mPGES-1-mediated conversion of $\mathrm{PGH}_{2}$ to $\mathrm{PGE}_{2}$ with $\mathrm{IC}_{50}$ values of 0.1 and $0.3 \mu \mathrm{M}$ respectively. Garcinol was found to suppress 5 -lipoxygenase product formations in intact human neutrophils and reduced $\mathrm{PGE}_{2}$ formation in interleukin-1 $\beta$ stimulated A549 human lung carcinoma cells as well as in human whole blood stimulated by lipopolysaccharide. Garcinol also interfered with isolated COX-1 enzyme $\left(\mathrm{IC}_{50}=12 \mu \mathrm{M}\right)$ and with the formation of COX-1-derived 12(S)-hydroxy-5-cis-8, 10-trans-heptadecatrienoic acid as well as thromboxane $B_{2}$ in human platelets. The high potency of garcinol in selectively suppressing $\mathrm{PGE}_{2}$ synthesis and 5-lipoxygenase product formations provides the molecular basis for its anti-inflammatory and anti-carcinogenic effects and rationalizes its therapeutic use [32].

\section{c. Anticancer activity}

The effects of garcinol and its oxidative derivatives have been investigated on the growth of HT-29 and HCT-116 colon cancer cells, as well as IEC- 6 and INT-407 which are the normal immortalized intestinal cells [33]. Garcinol and its derivatives showed potent growth-inhibitory effects on all intestinal cells, with $\mathrm{IC}_{50}$ values in the range of 3.2-21.4 $\mu \mathrm{M}$ after $72 \mathrm{hr}$ treatment. Garcinol was found to be more effective in inhibiting growth of cancer cells than that of normal immortalized cells. These results indicate that garcinol and its derivatives can inhibit intestinal cancer cell growth without affecting normal cells. However, it should be pointed out that at low concentrations garcinol can stimulate cell growth [33]. An earlier study investigated the modifying effects of dietary feeding of the compound on the development of azoxymethane (AOM)-induced colonic aberrant crypt foci (ACF) in male F344 rats [34]. The study also assessed the effects of garcinol on proliferating cell nuclear antigen (PCNA) index in ACF and activities of detoxifying enzymes such as glutath- 
ione S-transferase (GST) and quinone reductase (QR) in liver. It was observed that garcinol administration significantly lowers PCNA index in ACF and significantly elevates liver GST and QR activities. In addition, garcinol was also found to suppress $\mathrm{O}(2)(-)$ and $\mathrm{NO}$ generation and expression of iNOS and COX-2 proteins. These observations suggest possible chemopreventive role of garcinol [34]. In yet another report on the suppression of ACF formation in rats by garcinol [35], the beneficial effects of garcinol against tumor prevention in human colorectal cancer cell line, HT-29 were investigated. Matrigel analysis showed that exposure of HT-29 cells to $10 \mu \mathrm{M}$ garcinol inhibited cell invasion and decreased the dose-dependent tyrosine phosphorylation of focal adhesion kinase (FAK). Western blot analysis demonstrated that garcinol inhibits activation of the Src, MAPK/ERK, and PI3K/Akt signaling pathways. Additionally, these studies demonstrated that decreased MMP-7 protein levels in HT-29 cells result in sensitization to garcinol and that the compound significantly inhibits the expression of MMP-7 in IL-1betainduced HT-29 cells. Thus, garcinol reduces cell invasion and survival through the inhibition of FAK's downstream signaling [35].

In human leukemia HL-60 cells, garcinol has been reported to display strong growth inhibitory activity $\left(\mathrm{IC}_{50}\right.$ $=9.42 \mu \mathrm{M}$ ) through induction of caspase-3/CPP32 activity in a dose- and time-dependent manner and inducing degradation of poly (ADP-ribose) polymerase (PARP) protein [5]. This induction of apoptosis provides a pivotal mechanism for its cancer chemopreventive action. In a study comprising four human leukemia cells lines, loss of mitochondrial membrane potential was observed during garcinol-induced apoptosis [36]. Garcinol also modulates arachidonic acid metabolism by blocking the phosphorylation of cPLA2 and by decreasing iNOS protein level mediated via inhibition of STAT-1 activation. These activities may contribute to the anti-inflammatory and anticancer properties of garcinol and its derivatives [29].

Two new benzophenones corresponding to the 13-Omethyl ethers of garcinol and isogarcinol were tested for their inhibitory effects on Epstein-Barr virus early antigen activation induced by 12-O-tetradecanoylphorbol-13-acetate (TPA) in Raji cells and their radical-scavenging ability against 1,1-diphenyl-2-picrylhydrazyl (DPPH) was demonstrated [37]. The cyclized polyprenylbenzophenones showed comparable or stronger potential cancer chemopreventive activity when compared to glycyrrhetic acid, a known anti-tumor promoter. Yoshida and coworkers have demonstrated that dietary garcinol significantly decreases the incidence and multiplicity of 4-NQOinduced tongue neoplasms and pre-neoplasms as compared to the control diet [38]. It also significantly reduced the BrdU-labeling index and cyclin D1-positive cell ratio, suggesting reduction in cell proliferation activity in the tongue. The COX-2 expression in the tongue lesions was also suppressed. They concluded that dietary administration of garcinol inhibits 4-NQO-induced tongue carcinogenesis through suppression of increased cell proliferation activity in the target tissues and/or COX-2 expression in the tongue lesions [38].

The potent cytotoxic activity for the methanol extract of the fruit rinds of Garcinia indica against three human cancer cell lines, viz. colon (COLO-320-DM), breast (MCF-7) and liver (WRL-68) has been reported [39]. Fractionation of the methanol extract into hexane-, chloroform- and ethyl acetate-soluble portions was performed and their cytotoxic activity was evaluated. The ethyl acetate fraction was found to be the most effective as compared to the two other fractions. Thus, current results provide evidence for the potential of garcinol as a chemopreventive agent in carcinogenesis. Additionally, feeding garcinol-containing diets does not cause retardation of body weight gain and pathological alterations in liver and other organs including kidney, lung, heart, and esophagus, which is indicative of the low toxicity of the compound, which is a very attractive feature of any anti-cancer agent.

\section{d. Anti-HIV Activity}

Histone acetylation is a diagnostic feature of transcriptionally active genes [40]. The proper recruitment and function of histone acetyltransferases (HATs) and histone deacetylases (HDACs) are key regulatory steps for gene expression and cell cycle. Functional defects of either of these enzymes may lead to several diseases, including cancer. It has been reported that garcinol is a potent non-specific inhibitor of histone acetyltransferases p300 (IC50 = $7 \mu \mathrm{M}$ ) which strongly inhibited HAT activity-dependent chromatin transcription, whereas transcription from DNA template was not affected [40]. In order to find out more potent, specific, and less toxic inhibitors, Mantelingu et al. [41] synthesized and characterized several derivatives of isogarcinol (IG), a product of intramolecular cyclization of garcinol, by controlled modification and mono-substitution at $\mathrm{C}-14$ position. In this way they were able to synthesize 14-isopropoxy IG (LTK-13) and 14-methoxy IG (LTK-14) derivatives of isogarcinol. The di-substitution yielded 13, 14 di-isopropoxy IG (LTK-13A), 13, 14 dimethoxy IG (LTK-14A), 13, 14 di-acetoxy IG (LTK-15) and 13, 14 di-sulfoxy (LTK-19) isogarcinol compounds, respectively. It was found that the mono-substituted isogarcinol derivatives like LTK-13, -14, and di-substituted LTK-19 derivative could inhibit the p300-HAT activity but not the PCAF-HAT activity, although the parent isogarcinol compound inhibited HAT activities of both p300 and PCAF non-specifically. 
Interestingly, one of the derivatives, LTK-15, seemed to loose the HAT inhibition activity: it could inhibit the p300-mediated acetylation less than $10 \%$ and had no effect on PCAF-HAT activity. Furthermore, the other disubstituted isogarcinol derivatives, LTK-13A and LTK$14 \mathrm{~A}$, also lost their activity completely. The $\mathrm{IC}_{50}$ values, of LTK-13, -14, and -19, to inhibit p300- HAT activity were found to be 5-7 $\mu \mathrm{M}$, which is comparable to isogarcinol. In order to visualize the inhibition pattern of histone acetylation, HAT assay products were analyzed by fluorography followed by autoradiography. In agreement with filter-binding data, it was found that in the presence of 10 $\mu \mathrm{M}$ of LTK-13, -14 , and -19 , the p300-mediated acetylation of histones $\mathrm{H} 3$ and $\mathrm{H} 4$ were equally inhibited up to $85 \%-90 \%$ as compared to DMSO solvent control. The histone acetylation by PCAF (predominantly at histone H3) was not affected by LTK-13, -14 , and -19 . As expected, the presence of $10-\mu \mathrm{M}$ concentration of isogarcinol efficiently inhibited histone acetylation by both p300 and PCAF. However, dose-dependent inhibition of p300- HAT activity was observed in the presence of LTK-14. Significantly, HAT-activity of PCAF remained unchanged even in the presence of $50 \mu \mathrm{M}$ LTK14 and these chromatin modifying enzyme activities were not affected by the presence of isogarcinol and its derivatives. Taken together, the data suggests that the isogarcinol derivatives are specific inhibitors of p300-HAT activity $[41,42]$.

Since reversible acetylation of histone and non-histone proteins plays pivotal role in cellular homeostasis [43], dysfunction of histone acetyltransferases (HATs) is known to cause several diseases including cancer, neurodegenaration, asthma, diabetes, AIDS, and cardiac hypertrophy. Moreover, since p300 protein plays a critical role in cell growth, differentiation, and death, several of these functions require intrinsic HAT activity of p300-HAT; however, the molecular basis of p300 contribution toward diverse cellular processes is still unresolved [43]. Mantelingu et al. [41] have described the synthesis and characterization of a set of p300-HAT-specific small-molecule inhibitors derived from garcinol that are highly toxic to cells. They have shown that these specific inhibitors selectively block the p300-mediated acetylation of p53 in vivo. Furthermore, inhibition of p300-HAT down-regulates several genes but, significantly, few important genes are also up regulated. Remarkably, these inhibitors were found to be non-toxic to T cells, while inhibiting histone acetylation of HIV infected cells and consequently inhibiting the multiplication of HIV. Hence, garcinol holds tremendous therapeutic potential for different diseases including AIDS and cancer.

\section{e. Anti-ulcer activity}

Garcinol has potent free radical scavenging activity as judged from its interactions in three types of free radical generating systems. Its scavenging activity against hydroxyl radical has been found to be stronger than that of $\alpha$-Tocopherol [17] while its other scavenging activities were found to be slightly weaker. Since hydroxyl radical is regarded as the most damaging Reactive Oxygen Species (ROS), garcinol is expected to be useful for preventing diseases caused by the hydroxyl radical damages such as stress-induced gastric ulcer [44,45] and NSAID druginduced gastric ulcers $[46,47]$. In the water immersion stress model, Yamaguchi et al. have shown that garcinol suppressed gastric injury formation to almost same extent as cetraxate hydrochloride as a positive control [28]. It also prevented indomethacin-induced gastric injury. These results suggest that garcinol may have potential as an anti-ulcer drug. Although mechanism of its anti-ulcer activity is not yet understood, it may be speculated that the compound may scavenge reactive oxygen species on the surface of gastric mucosa, thus protecting cells from injury [28].

\section{Structure-activity considerations for garcinol}

It has been clearly established that the C-3 kenotic group and the phenolic ring bearing hydroxyl group are the principal oxidation sites of garcinol generating its oxidized products during metabolic transformations some of which are also biologically active $[18,19]$. It has also been found that the 1, 2 carbon-carbon double bond of the $\alpha$, $\beta$-unsaturated ketone is important for apoptosis-inducing activity and cytotoxicity of garcinol [5]. The double bond of the isoprenyl group is also a principal site of the antioxidant reaction of garcinol; however, compounds without having such substitution and bearing structural resemblance to garcinol, like curcumin, have been found to be potent antioxidants [48]. The isoprenyl chain of garcinol consists of hydrophobic faces, which are important for its binding to biological targets [49].

\section{Chalcones as a garcinol analoges}

Kostanecki, who pioneered work in the synthesis of natural coloring compounds, first coined the term 'chalcone'. An interesting feature of chalcones is that they serve as starting materials for another class of naturally occurring and widely distributed pigments, flavones [50]. They are considered to be precursors of flavonoids and isoflavonoids, which are abundant in edible plants. Chalcones are intermediates in the synthesis of flavones. Chemically they are open-chain flavonoids in which the two aromatic rings are joined by a three-carbon $\alpha, \beta$-unsaturated carbonyl system (1, 3-diphenyl-2-propen-1-one). Chalcones exhibit many pharmacological activities including antileishmanial [51], anti-inflammatory [52,53], anti-mitotic [54], anti-invasive [55], anti-tuberculosis [56], anti-fungal [57], cysteinyl leukotriene receptor-1 antagonist [58], anti-malarial $[59,60]$, anti-plasmodial, antitumor, immunosuppressive, antioxidant [61], anti-fibrogenic and modulation of P-glycoprotein-mediated multi-drug resistance [62]. Recent studies have shown that chalcones 
inhibit cancer cell proliferation in vivo and are effective agents against skin cancers $[63,64]$. They also induce apoptosis in various cell types, including breast cancers [65]. Several oxygenated chalcones; hydroxyl chalcones, bis-chalcones and quinolinyl chalcone analogs exhibit anti-malarial activity $[66,67]$. Some chalcones also demonstrate their ability to block voltage-dependent potassium channels [68]. These limited yet interesting studies clearly suggest the beneficial effects of chalcones and other derivatives in human health and diseases.

\section{a. Structural chemistry of chalcones}

Chalcones consist of two aromatic rings in trans configuration, separated by three carbons, of which two are connected by double bond while the third is a carbonyl group [69]. Garcinol is an example of prenylated chalcones, containing two aromatic rings separated by carbonyl group (Figure 2), which is structurally similar to curcumin that resembles chalcones when opened [5]. Genealogical studies have shown that chalcones have evolved prior to garcinol, and chalcones are derived from three acetates and cinnamic acid as shown in Figure 2. Since chalcones are efficient precursors of isoflavonoids, the required aryl migration of ring $\mathrm{B}$ from the beta position to the alpha position of the phenylpropanoid precursor must take place after formation of the basic $\mathrm{C}_{15}$ skeleton [70]. A vast number of naturally occurring chalcones are polyhydroxylated in the aryl rings. The radical quenching properties of the phenolic groups present in many chalcones have raised interest in using these compounds as therapeutic agents or food preservatives [71].

Chalcones are readily synthesized by the base-catalyzed Claisen-Schimdt condensation of an aldehyde and appro-

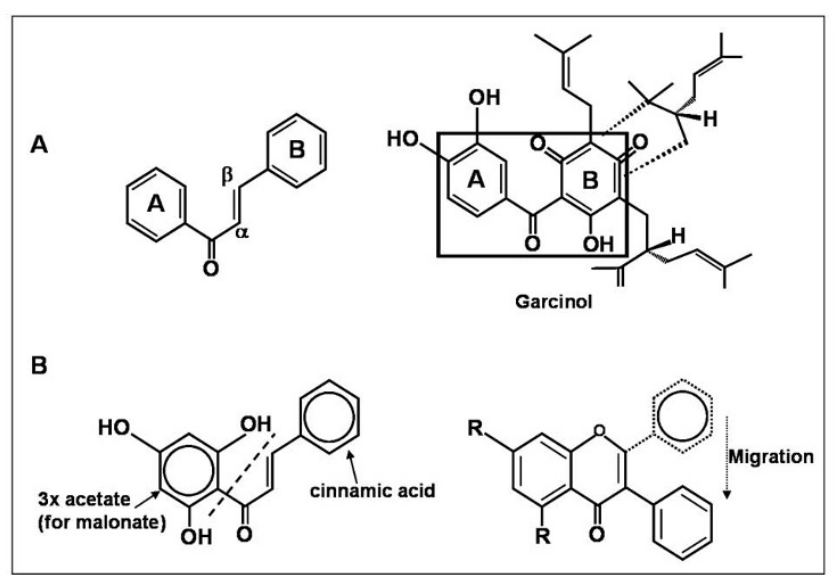

Figure 2

A. Structural similarity between chalcone and garcinol moieties. B. Formation of chalcone and migration of ring $B$. priate ketone in a polar solvent like methanol or ethanol (Figure 3) [61]. The synthesis of hydroxylated chalcones by the Claisen-Schimdt method requires protection of the phenolic hydroxyl groups on aldehyde and ketone (except ortho-hydroxyl groups), generally as tetrahydropyranyl (THP), methoxymethyl (MOM), or methoxyethoxymethyl (MEM) ethers. The MOM and MEM ethers are cleaved in the presence of acid, under such conditions; and hence the side reactions compromise the yield of the final product [72]. The $\mathrm{C} \alpha-\mathrm{C} \beta$ double bond in the 'enone' moiety of chalcones can adopt $Z$ or E configuration. The E-isomer is thermodynamically more stable and almost all chalcones are isolated in this form. Iwata and co-workers have reported isomerization of $\mathrm{E}$-chalcone to the $\mathrm{Z}$ form by exposing the methanolic solution of the chalcone to normal visible light [73]. Interestingly, the $\mathrm{Z}$ isomer showed more potent antitumor activity than the original $\mathrm{E}$ form. Photoisomerization of the predominant $\mathrm{E}$ isomer to the $\mathrm{Z}$ isomer may cause change in biological activity and the ease with which the reaction occurs suggest that it is prudent to protect solution of chalcones from light.

Ducki et al. have noted that the two bonds were positioned cis with respect to each other in several X-ray crystal structures of chalcones [54]. The s-cis conformer was more stable than the s-trans conformer by, at least, $3.9 \mathrm{~kJ} / \mathrm{mol}$. On the other hand, when a methyl group was introduced at the $C \alpha$ position, the disposition of the carbonyl and $\mathrm{C} \alpha-\mathrm{C} \beta$ double bonds altered to the trans orientation. For these $\alpha$-methyl chalcones, molecular mechanics calculations showed that the minimum energy conformers were s-trans and no s-cis conformation was evident within a 10$\mathrm{kJ} / \mathrm{mol}$ range of the global energy minimum. The $\alpha$ methyl group also caused significant loss of planarity between ring $A$ and the enone $\left(\theta 156-88^{\circ}\right)$. The $\alpha$-methylchalcones are found to have greater cytotoxic activity against a human leukemia cell line than the unsubstantiated analogues. Their unique geometrical features were

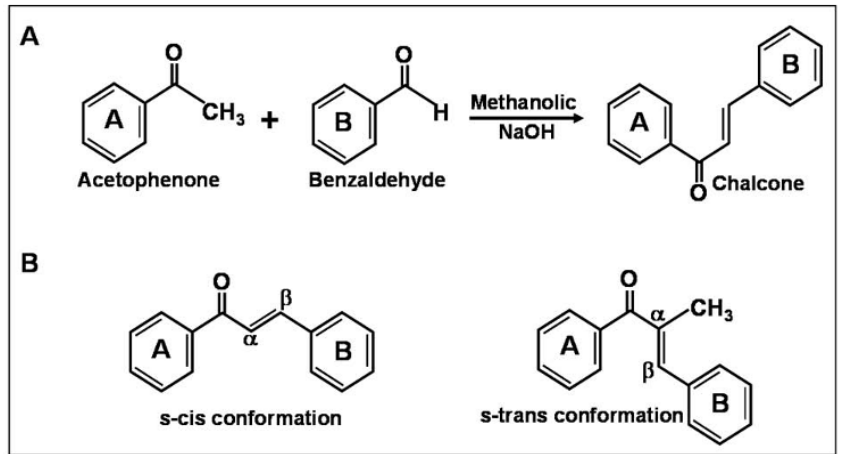

Figure 3

A. Scheme of synthesis of chalcones. B. s-cis and s-trans conformation of chalcones. 
cited as a possible factor contributing to the enhanced biological activity.

\section{b. Biological Activities of chalcones}

Xia and coworkers were the first to demonstrate improved anti-proliferative activity of chalcones with substituted amino groups [74]. LeBlanc et al. have shown that methoxylated chalcones with a 3'-amino group had sub-micromolar $\mathrm{IC}_{50}$ values against murine melanoma B16 cells [75]. Dimmock and coworkers proposed that the presence of amino function increases the reactivity of chalcones as Michael acceptors and subsequently their anti-proliferative activity [76]. They postulated that the amino function would be protonated at low $\mathrm{pH}$ environment normally encountered in tumors. The electron withdrawing effect of the protonated ammonium function would enhance the electrophilicity of the $\beta$-carbon in the enone linkage, hence increasing its reactivity as a Michael acceptor [77]. Liquorice has been used in China for the treatment of gastric and duodenal ulcers, bronchial asthma, Addison's disease, poisoning by food and drugs and skin disease such as eczema and urticaria [78]. It still finds medicinal application because of its wide-ranging therapeutic properties, including relief from rheumatic and other types of pain and healing effect on ulcers. The crude extract of Liquorice has also found commercial use as a food additive in Japan since it contains the sweetening principle glycyrrhizin. The Liquorice extracts contains a chalcone, viz. Isoliquritigenin, which is currently in use as a phosphodiesterase III inhibitor for the treatment of cardiovascular diseases [79]. In the Far East countries such as Korea, Japan, and China, another chalcone compound called 'Butein' has also been traditionally used for treatment of pain, thrombotic disease, stomach cancer, and parasitic infection as well as a food additive [80].

Anti-angiogenic effect of xanthochymol and Isoxanthochymol, the chalcones isolated from the hop, has been reported [81]. A dose-dependant reduction of newly formed capillary growth by xanthochymol was observed, at a concentration range of $0.5-10 \mu \mathrm{M}\left(\mathrm{IC}_{50}\right.$ value of 2.2 $\mu \mathrm{M})$ under in vitro conditions. Later, it was shown that xanthochymol repressed both the NF- $\mathrm{BB}$ and Akt pathways in the endothelial cells, indicating that components of these pathways are major targets in the molecular mechanism of this compound [82]. Xanthochymol also reduced VEGF secretion, decreased cell invasion and metalloprotease production in acute and chronic myelogenous leukemia cell lines [83]. 2'-hydroxychalcones, 4'hydroxychalcones and 2', 4'-dihydroxychalcones inhibit 12-Lipoxygenase and cyclooxygenase enzymes in the mouse epidermis [84] and two synthetic 2'-hydroxychalcones that exert topical anti-inflammatory effects in mice have also been reported [85]. The good selective inhibitory effects of 2', 5' dihydroxychalcones on arachidonic acid-induced platelet aggregation have been suggested
[86] and these reports, taken together, suggest that some hydroxy chalcones might be promising antithrombotic or anti-inflammatory agents.

Saxena and coworkers grafted chalcone derivatives on estradiol framework some of which showed potent anticancer activity against some human cancer cell lines [87]. Thus, compounds $\mathrm{B}$ and $\mathrm{C}$ in Figure 4 show potent activity against estrogen receptor-positive and hormonedependent human breast cancer cell lines, MCF-7. Chalcone A was further modified to yield corresponding indanone derivative (C) using the Nazarov reaction, which showed better activity than the parent compound against MCF-7 breast cancer cell line. Active anticancer derivatives were also evaluated for osmotic hemolysis using the erythrocyte as a model system. It was observed that chalcone derivatives showing cytotoxicity against cancer cell lines did not affect the fragility of erythrocytes and hence may be considered as non-toxic to normal cells; however, further research in this area is urgently needed. Nitric oxide production by trimethoxy chalcone derivatives, with various patterns of fluorination, has also been evaluated [88]. One of this compounds, 2, 4, 6-trimethoxy-20-trifluoromethylchalcone, inhibited the production of NO and prostaglandin E2 in lipopolysaccharidestimulated RAW 264.7 macrophage cells. The inhibition (76.3\% inhibition at $10 \mu \mathrm{M}$ concentration) was dosedependent without any evidence of a cytotoxic effect. It was suggested that NO reduction was a consequence of inhibition of the expression $\mathrm{PGE}_{2}$ accumulation. The fluorinated chalcones tested by Nakamura et al. showed 5lipoxygenase inhibition on rat basophilic leukemia-1 (RBL-1) cells and inhibitory action on $\mathrm{Fe}^{3+}$-ADP induced NADPH-dependent lipid peroxidation in rat liver microsomes [89]. The potencies were comparable or better than those of the lead compound, viz. 3,4-dihydroxychalcone. The structure of fluorinated chalcone is presented in Figure 5.

\section{Why Chalcones are good analogs of Garcinol? I. Structural Similarity}

Chemically, garcinol is a polyisoprenylated chalcone containing two aromatic rings separated by a carbonyl group. The $\alpha, \beta$-unsaturated ketone system important for the apoptosis-inducing activity is present between the two rings in case of chalcones but within the ring $\mathrm{B}$ in case of garcinol (Figure 2). Garcinol differs from chalcones with the presence of isoprenyl groups, which makes its structure more complex and adds to its antioxidant activity [5].

\section{Reaction Similarity}

The reducibility of the carbonyl function in chalcones and its relationship to biological activity has been investigated [90]. In quantitative structure-activity relationships (QSAR), the reducibility of the carbonyl function serves as an indirect indicator of the electron density on the carbo- 


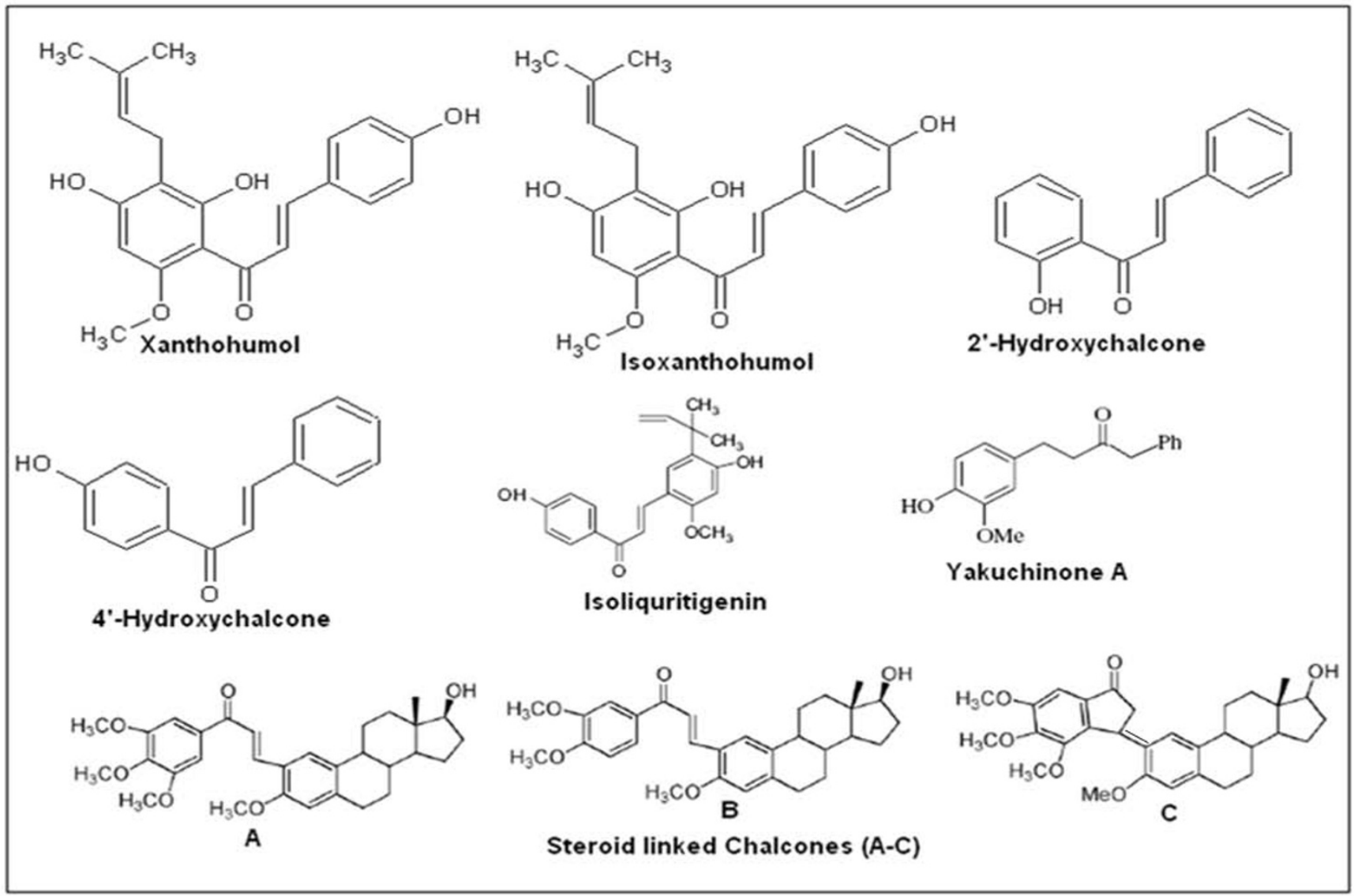

Figure 4

Structures of some therapeutically active chalcone compounds.

nyl function. A readily reducible carbonyl group would imply that the carbonyl carbon is electron-deficient. Electron delocalization along the $\alpha, \beta$-unsaturated chain would render the $\beta$-carbon electron deficient and, accordingly, more susceptible to attack by thiols and other nucleophiles. Thus, one would expect a relationship between

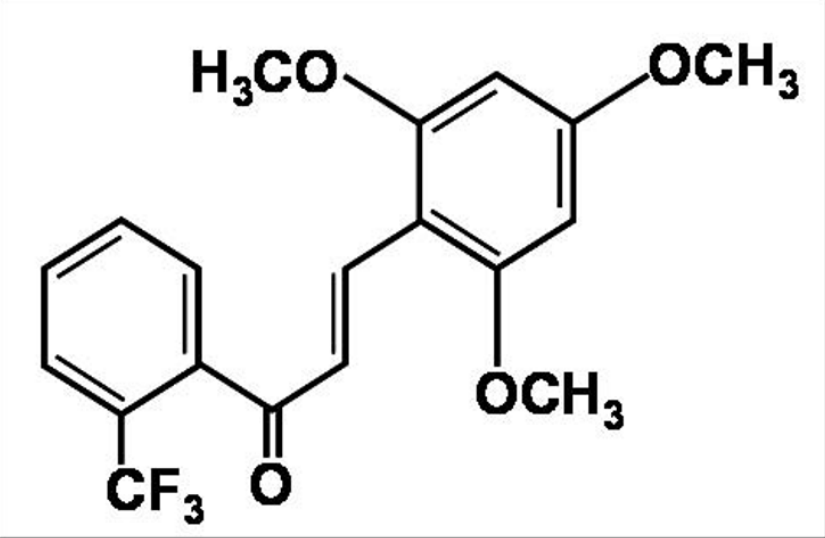

Figure 5

Fluorinated chalcone: as anti-inflammatory agent. the reducibility of the carbonyl bond (for example, measured in terms of reduction peak potentials in cyclic voltametry) and the susceptibility to nucleophilic attack at the $\beta$-carbon. On the other hand, in vivo reduction of the carbonyl group to an alcohol is unlikely to predominate, as seen from the in vitro biotransformation of 4-dimethylamino-4' (imidazol-1-yl) chalcone [91]. In case of garcinol no reactions has been reported but presence of carbonyl group may suggest that such reactions could occur.

\section{Similarity in Biological Activities}

Chalcones as well as garcinol are reported as potent antioxidants and have been screened for their anti-inflammatory, anti-cancer, anti-HIV, anti-biotic, anti-fungal and anti-tumor activities. Structurally, chalcones are more easily amenable for structural modification and optimization for some selective biological activity than garcinol.

\section{Metal Complexation}

The synthesis and structural studies of complexes of Co (II), Ni (II), Cu (II), Zn (II) and Cd (II) with substituted chalcones has been reported [92]. In general, for metal 
complexation reactions, the Schiff derivatives of the chalcones are preferred which not only offer selectivity in metal complexation reactions but also an enhancement in biological activities. As yet no metal complexes of garcinol have been reported.

\section{Conclusions and perspectives}

The chalcone garcinol is a potent antioxidant and anticancer agent among its many other biological effects as discussed above. Its structure makes it a very efficient scavenger of oxygen free radicals and an excellent inhibitor of NO. Various biological activities of garcinol have been reported (summarized in Table 1) and most of them relate to its antioxidant nature. More recently, garcinol has generated considerable interest among cancer researchers, and emerging data suggests its ability to protect against chemically-induced carcinogenesis, as well as highlights its potential use as a chemopreventive agent. An interesting observation in this context is its ability to modulate $N F-\kappa B$, directly or indirectly $[29,31]$. Since $N F-\kappa B$ is known to be a key player in the progression of human cancers $[93,94]$, its suppression by garcinol indicates a putative potential molecular target of this compound, which requires thorough testing for establishing the scientific rationale for the use of garcinol as an anti-cancer agent prior to its use as a novel therapeutic agent for the treatment of human malignancies. Our preliminary results (unpublished data) suggest an anti-cancer activity of garcinol against human cancer cell lines through induction of apoptosis, and inhibition of NF- $\kappa \mathrm{B}-\mathrm{DNA}$ binding activity.

Interestingly, induction of apoptosis by garcinol occurs possibly through the activation of caspases as reported $[5,36]$, and our laboratory is beginning to conduct mechanistic studies in support of the role of garcinol as antitumor agent against human malignancies, particularly in view of the promising data that has emerged in recent years. Another factor that is starting to generate interest among researchers is the resemblance of the structure of garcinol to that of curcumin (Figure 1). In a direct comparison between these two compounds, it was shown that garcinol has better anti-tumor as well as apoptosis inducing activity [5]. Moreover, garcinol has been shown to

Table I: Summary of reported biological activities of garcinol

\begin{tabular}{|c|c|c|}
\hline Activity & Observations & Reference \\
\hline \multirow[t]{6}{*}{ Anti-oxidant } & Efficient scavenging of free radicals & Yamaguchi et al. [17] \\
\hline & & Yamaguchi et al.[28] \\
\hline & Inhibition of $\mathrm{NO}$ and $\mathrm{H}_{2} \mathrm{O}_{2}$ production & Sang et al. [18] \\
\hline & Inhibition of NO and iNOS Generation & Sang et al. [19] \\
\hline & Inhibition of iNOS and COX-2 expression & Liao et al. [3। ] \\
\hline & Inhibition of $\mathrm{NO}$ accumulation & Liao et al. [30] \\
\hline \multirow[t]{4}{*}{ Anti-bacterial } & Activity against methicillin-resistant Staphylococcus aureus & linuma et al. [23] \\
\hline & & Rukachaisirikul et al. [22] \\
\hline & Efficient killing of Helicobacter pylori & Chatterjee et al. [20] \\
\hline & & Chatterjee et al. [21] \\
\hline \multirow[t]{8}{*}{ Anti-cancer } & Chemoprevention of colon tumorigenesis & Tanaka et al. [34] \\
\hline & Induction of caspase-3-mediated apoptosis & Pan et al. [5] \\
\hline & Loss of mitochondrial potential and activation of caspase- 3 & Matsumoto et al. [36] \\
\hline & Induction of apoptosis & Balasubramanyam et al. [40] \\
\hline & Inhibition of tongue carcinogenesis & Yoshida et al. [38] \\
\hline & Modulation of arachidonic acid metabolism and inhibition of STAT-I & Hong et al. [29] \\
\hline & Selective killing of colon cancer cells & Hong et al. [33] \\
\hline & Induction of apoptosis and inhibition of cell invasion & Liao et al. [35] \\
\hline
\end{tabular}


modulate various key signaling pathways, as discussed above, which is consistent with the pleiotropic activity of garcinol. In summary, the available literature on garcinol points to its protective role against a number of human ailments and diseases, particularly cancer; however, detailed mechanistic studies are needed in order to fully appreciate the potential beneficial effects of this compound in human health and diseases.

\section{Declaration of competing interests}

The authors declare that they have no competing interests.

\section{Authors' contributions}

SP and FHS conceived of the study and participated in its design. SP, AA and NO conducted the review of literature and drafted the manuscript. Principal investigator, FHS provided the laboratory facility and financial support and helped in the writing and edition of manuscript. All authors read and approved the final manuscript.

\section{Acknowledgements}

SP would like to thank Dr. P. D. Patil, Dr. K. B. Powar and Dr. B. S. Mane for their interest and help with this manuscript.

\section{References}

I. Heymsfield SB, Allison DB, Vasselli JR, Pietrobelli A, Greenfield D, Nunez C: Garcinia cambogia (hydroxycitric acid) as a potential antiobesity agent: a randomized controlled trial. JAMA 1998, 280:1596-1600.

2. Mishra A, Bapat MM, Tilak JC, Devasagayam TP: Antioxidant activity of Garcinia indica (kokam) and its syrup. Current Science 2006, $91: 90-93$.

3. Tamil Selvi A, Joseph GS, Jayaprakasha GK: Inhibition of growth and aflatoxin production in Aspergillus flavus by Garcinia indica extract and its antioxidant activity. Food Microbiology 2003, 20:455-460.

4. Thadhani VM, Jansz ER, Peiris H: Effect of exogenous histidine and Garcinia cambogia on histamine formation in skipjack (Katsuwonus pelamis) homogenates. Int J Food Sci Nutr 2002, 53:29-34.

5. Pan MH, Chang WL, Lin-Shiau SY, Ho CT, Lin JK: Induction of apoptosis by garcinol and curcumin through cytochrome c release and activation of caspases in human leukemia HL-60 cells. J Agric Food Chem 200 I, 49: | 464-|474.

6. Chattopadhyay SK, Kumar S: Liquid chromatography-tandem mass spectrometry method for identification and quantification of two biologically active polyisoprenylated benzophenones, isoxanthochymol and camboginol, in Garcinia species. Biomed Chromatogr 2007, 2 I: I I 59- I I65.

7. Kumar S, Chattopadhyay SK: High-performance liquid chromatography and LC-ESI-MS method for the identification and quantification of two biologically active polyisoprenylated benzophenones xanthochymol and isoxanthochymol in different parts of Garcinia indica. Biomed Chromatogr 2007, 21:139-163.

8. Chattopadhyay SK, Kumar S: Identification and quantification of two biologically active polyisoprenylated benzophenones xanthochymol and isoxanthochymol in Garcinia species using liquid chromatography-tandem mass spectrometry. J Chromatogr B Analyt Technol Biomed Life Sci 2006, 844:67-83.

9. Chattopadhyay SK, Kumar S: A rapid liquid chromatographytandem mass spectrometry method for quantification of a biologically active molecule camboginol in the extract of Garcinia cambogia. Biomed Chromatogr 2007, 2 I:55-66.

10. Kumar S, Sharma S, Chattopadhyay SK: High-performance liquid chromatography and LC-ESI-MS method for identification and quantification of two isomeric polyisoprenylated benzo- phenones isoxanthochymol and camboginol in different extracts of Garcinia species. Biomed Chromatogr 2009, 23:888-907.

II. Jayaprakasha GK, Sakariah KK: Determination of organic acids in leaves and rinds of Garcinia indica (Desr.) by LC. J Pharm Biomed Anal 2002, 28:379-384.

12. Jena BS, Jayaprakasha GK, Singh RP, Sakariah KK: Chemistry and biochemistry of (-)-hydroxycitric acid from Garcinia. J Agric Food Chem 2002, 50:10-22.

13. Krishnamurthy N, Lewis YS, Ravindranath B: On the structures of garcinol, isogarcinol and camboginol. Tetrahedron Letters 1981, 22:793-796.

14. Krishnamurthy N, Ravindranath B, Row TNG, Venkatesan K: Crystal and molecular structure of isogarcinol. Tetrahedron Letters 1982, 23:2233-2236.

I5. Masullo M, Bassarello C, Suzuki H, Pizza C, Piacente S: Polyisoprenylated benzophenones and an unusual polyisoprenylated tetracyclic xanthone from the fruits of Garcinia cambogia. J Agric Food Chem 2008, 56:5205-5210.

16. Hamed W, Brajeul S, Mahuteau-Betzer F, Thoison O, Mons S, Delpech B, Hung NV, Sevenet T, Marazano C: Oblongifolins A-D, Polyprenylated Benzoylphloroglucinol Derivatives from Garcinia oblongifolia. Journal of Natural Products 2006, 69:774-777.

17. Yamaguchi F, Ariga T, Yoshimura Y, Nakazawa H: Antioxidative and anti-glycation activity of garcinol from Garcinia indica fruit rind. J Agric Food Chem 2000, 48: 180-185.

18. Sang S, Pan MH, Cheng X, Bai N, Stark RE, Rosen RT, Lin-Shiau SY, Lin JK, Ho CT: Chemical studies on antioxidant mechanism of garcinol: analysis of radical reaction products of garcinol and their antitumor activities. Tetrahedron 200I, 57:993I-9938.

19. Sang S, Liao CH, Pan MH, Rosen RT, Lin-Shiau SY, Lin JK, Ho CT: Chemical studies on antioxidant mechanism of garcinol: analysis of radical reaction products of garcinol with peroxyl radicals and their antitumor activities. Tetrahedron 2002, 58:10095-10102.

20. Chatterjee A, Bagchi D, Yasmin T, Stohs SJ: Antimicrobial effects of antioxidants with and without clarithromycin on Helicobacter pylori. Mol Cell Biochem 2005, 270: I25-I30.

21. Chatterjee A, Yasmin T, Bagchi D, Stohs SJ: The bactericidal effects of Lactobacillus acidophilus, garcinol and Protykin compared to clarithromycin, on Helicobacter pylori. Mol Cell Biochem 2003, 243:29-35.

22. Rukachaisirikul V, Naklue W, Sukpondma Y, Phongpaichit S: An antibacterial biphenyl derivative from Garcinia bancana MIQ. Chem Pharm Bull (Tokyo) 2005, 53:342-343.

23. linuma M, Tosa H, Tanaka T, Kanamaru S, Asai F, Kobayashi Y, Miyauchi K, Shimano R: Antibacterial activity of some Garcinia benzophenone derivatives against methicillin-resistant Staphylococcus aureus. Biol Pharm Bull 1996, I9:3 I I-3 I4.

24. Tosa H, linuma M, Tanaka T, Nozaki H, Ikeda S, Tsutsui K, Tsutusi K, Yamada M, Fujimori S: Inhibitory activity of Xanthone derivatives isolated from some guttiferaeous plants against DNA topoisomerases I and II. CHEMICAL \& PHARMACEUTICAL BULLETIN 1997, 45:418-420.

25. Bakana P, Claeys M, Totte J, Pieters LA, Van HL, Tamba V, Berghe DA Van den, Vlietinck AJ: Structure and chemotherapeutical activity of a polyisoprenylated benzophenone from the stem bark of Garcinia huillensis. J Ethnopharmacol 1987, 2 I:75-84.

26. Lenta BN, Vonthron-Senecheau C, Weniger B, Devkota KP, Ngoupayo J, Kaiser M, Naz Q, Choudhary MI, Tsamo E, Sewald N: Leishmanicidal and cholinesterase inhibiting activities of phenolic compounds from Allanblackia monticola and Symphonia globulifera. Molecules 2007, I 2:I548-I557.

27. Ciochina R, Grossman RB: Polycyclic polyprenylated acylphloroglucinols. Chem Rev 2006, I06:3963-3986.

28. Yamaguchi F, Saito M, Ariga T, Yoshimura Y, Nakazawa H: Free radical scavenging activity and antiulcer activity of garcinol from Garcinia indica fruit rind. J Agric Food Chem 2000, 48:2320-2325.

29. Hong J, Sang S, Park HJ, Kwon SJ, Suh N, Huang MT, Ho CT, Yang CS: Modulation of arachidonic acid metabolism and nitric oxide synthesis by garcinol and its derivatives. Carcinogenesis 2006, 27:278-286.

30. Liao $\mathrm{CH}$, Ho CT, Lin JK: Effects of garcinol on free radical generation and NO production in embryonic rat cortical neurons and astrocytes. Biochem Biophys Res Commun 2005, 329:|306-|3|4. 
31. Liao CH, Sang S, Liang YC, Ho CT, Lin JK: Suppression of inducible nitric oxide synthase and cyclooxygenase- 2 in downregulating nuclear factor-kappa B pathway by Garcinol. Mol Carcinog 2004, 4 I: | 40- I 49 .

32. Koeberle A, Northoff $H$, Werz $O$ : Identification of 5-lipoxygenase and microsomal prostaglandin E2 synthase-I as functional targets of the anti-inflammatory and anti-carcinogenic garcinol. Biochem Pharmacol 2009, 77:1513-1521.

33. Hong J, Kwon SJ, Sang S, Ju J, Zhou JN, Ho CT, Huang MT, Yang CS Effects of garcinol and its derivatives on intestinal cell growth: Inhibitory effects and autoxidation-dependent growth-stimulatory effects. Free Radic Biol Med 2007, 42:|2||-|22|

34. Tanaka T, Kohno H, Shimada R, Kagami S, Yamaguchi F, Kataoka S, Ariga T, Murakami A, Koshimizu K, Ohigashi H: Prevention of colonic aberrant crypt foci by dietary feeding of garcinol in male F344 rats. Carcinogenesis 2000, 2 1: I 183-1 I89.

35. Liao CH, Sang S, Ho CT, Lin JK: Garcinol modulates tyrosine phosphorylation of FAK and subsequently induces apoptosis through down-regulation of Src, ERK, and Akt survival signaling in human colon cancer cells. J Cell Biochem 2005, 96:155-169.

36. Matsumoto K, Akao Y, Kobayashi E, Ito T, Ohguchi K, Tanaka T, linuma M, Nozawa $Y$ : Cytotoxic benzophenone derivatives from Garcinia species display a strong apoptosis-inducing effect against human leukemia cell lines. Biol Pharm Bull 2003, 26:569-57।.

37. Ito C, Itoigawa M, Miyamoto $\mathrm{Y}$, Onoda S, Rao KS, Mukainaka T, Tokuda $\mathrm{H}$, Nishino $\mathrm{H}$, Furukawa $\mathrm{H}$ : Polyprenylated benzophenones from Garcinia assigu and their potential cancer chemopreventive activities. I Nat Prod 2003, 66:206-209.

38. Yoshida K, Tanaka T, Hirose Y, Yamaguchi F, Kohno H, Toida M, Hara A, Sugie S, Shibata T, Mori H: Dietary garcinol inhibits 4-nitroquinoline I-oxide-induced tongue carcinogenesis in rats. Cancer Lett 2005, 221:29-39.

39. Kumar S, Chattopadhyay SK, Darokar MP, Garg A, Khanuja SP: Cytotoxic activities of xanthochymol and isoxanthochymol substantiated by LC-MS/MS. Planta Med 2007, 73:|452-| 456.

40. Balasubramanyam K, Altaf M, Varier RA, Swaminathan V, Ravindran A Sadhale PP, Kundu TK: Polyisoprenylated benzophenone, garcinol, a natural histone acetyltransferase inhibitor, represses chromatin transcription and alters global gene expression. Biol Chem 2004, 279:33716-33726.

4I. Mantelingu K, Reddy BA, Swaminathan V, Kishore AH, Siddappa NB, Kumar GV, Nagashankar G, Natesh N, Roy S, Sadhale PP, Ranga U, Narayana C, Kundu TK: Specific inhibition of p300-HAT alters global gene expression and represses HIV replication. Chem Biol 2007, I 4:645-657.

42. Sarli V, Giannis A: Selective inhibition of CBP/p300 HAT. Chem Biol 2007, I 4:605-606.

43. Arif M, Kumar GV, Narayana C, Kundu TK: Autoacetylation induced specific structural changes in histone acetyltransferase domain of p300: probed by surface enhanced Raman spectroscopy. J Phys Chem B 2007, I I I: I I877-I I879.

44. Das D, Bandyopadhyay D, Bhattacharjee M, Banerjee RK: Hydroxyl radical is the major causative factor in stress-induced gastric ulceration. Free Radic Biol Med 1997, 23:8-18.

45. Das D, Bandyopadhyay D, Banerjee RK: Oxidative inactivation of gastric peroxidase by site-specific generation of hydroxyl radical and its role in stress-induced gastric ulceration. Free Radic Biol Med 1998, 24:460-469.

46. Vaananen PM, Meddings JB, Wallace JL: Role of oxygen-derived free radicals in indomethacin-induced gastric injury. $\mathrm{Am} J$ Physiol 1991, 261:G470-G475.

47. Yoshikawa T, Naito Y, Kishi A, Tomii T, Kaneko T, linuma S, Ichikawa $\mathrm{H}$, Yasuda M, Takahashi S, Kondo M: Role of active oxygen, lipid peroxidation, and antioxidants in the pathogenesis of gastric mucosal injury induced by indomethacin in rats. Gut 1993 , 34:732-737.

48. Aggarwal BB, Sung B: Pharmacological basis for the role of curcumin in chronic diseases: an age-old spice with modern targets. Trends Pharmacol Sci 2009, 30:85-94.

49. Roux D, Hadi HA, Thoret S, Guenard D, Thoison O, Pais M, Sevenet $T$ : Structure-activity relationship of polyisoprenyl benzophenones from Garcinia pyrifera on the tubulin/microtubule system. J Nat Prod 2000, 63:1070-1076.
50. Dimmock JR, Elias DW, Beazely MA, Kandepu NM: Bioactivities of chalcones. Curr Med Chem 1999, 6: I I25-I I49.

5I. Nielsen SF, Christensen SB, Cruciani G, Kharazmi A, Liljefors T: Antileishmanial chalcones: statistical design, synthesis, and three-dimensional quantitative structure-activity relationship analysis. I Med Chem 1998, 41:48I 9-4832.

52. Ko HH, Tsao LT, Yu KL, Liu CT, Wang JP, Lin CN: Structure-activity relationship studies on chalcone derivatives. the potent inhibition of chemical mediators release. Bioorg Med Chem 2003, II:105-III.

53. Herencia F, Ferrandiz ML, Ubeda A, Dominguez JN, Charris JE, Lobo GM, Alcaraz MJ: Synthesis and anti-inflammatory activity of chalcone derivatives. Bioorg Med Chem Lett 1998, 8: I I69-1 174.

54. Ducki S, Forrest R, Hadfield JA, Kendall A, Lawrence NJ, McGown AT, Rennison D: Potent antimitotic and cell growth inhibitory properties of substituted chalcones. Bioorg Med Chem Lett 1998, 8:105I-1056.

55. Mukherjee S, Kumar V, Prasad AK, Raj HG, Bracke ME, Olsen CE, Jain SC, Parmar VS: Synthetic and biological activity evaluation studies on novel I,3-diarylpropenones. Bioorg Med Chem 200I, 9:337-345.

56. Lin YM, Zhou Y, Flavin MT, Zhou LM, Nie W, Chen FC: Chalcones and flavonoids as anti-tuberculosis agents. Bioorg Med Chem 2002, 10:2795-2802

57. Lopez SN, Castelli MV, Zacchino SA, Dominguez JN, Lobo G, Charris-Charris J, Cortes JC, Ribas JC, Devia C, Rodriguez AM, Enriz RD: In vitro antifungal evaluation and structure-activity relationships of a new series of chalcone derivatives and synthetic analogues, with inhibitory properties against polymers of the fungal cell wall. Bioorg Med Chem 200I, 9:1999-2013.

58. Zwaagstra ME, Timmerman H, Tamura M, Tohma T, Wada Y, Onogi $\mathrm{K}$, Zhang MQ: Synthesis and structure-activity relationships of carboxylated chalcones: a novel series of CysLTI (LTD4) receptor antagonists. IMed Chem 1997, 40:1075-1089.

59. Li R, Kenyon GL, Cohen FE, Chen X, Gong B, Dominguez JN, Davidson E, Kurzban G, Miller RE, Nuzum EO: In vitro antimalarial activity of chalcones and their derivatives. J Med Chem 1995 , 38:503।-5037.

60. Liu M, Wilairat P, Go ML: Antimalarial alkoxylated and hydroxylated chalcones [corrected]: structure-activity relationship analysis. J Med Chem 200I, 44:4443-4452.

61. Go ML, Wu X, Liu XL: Chalcones: an update on cytotoxic and chemoprotective properties. Curr Med Chem 2005, I 2:48I-499.

62. Bois F, Boumendjel A, Mariotte AM, Conseil G, Di PA: Synthesis and biological activity of 4-alkoxy chalcones: potential hydrophobic modulators of P-glycoprotein-mediated multidrug resistance. Bioorg Med Chem 1999, 7:269|-2695.

63. Satomi Y: Inhibitory effects of 3'-methyl-3-hydroxy-chalcone on proliferation of human malignant tumor cells and on skin carcinogenesis. Int J Cancer 1993, 55:506-5I4.

64. Yamamoto S, Aizu E, Jiang H, Nakadate T, Kiyoto I, Wang JC, Kato R: The potent anti-tumor-promoting agent isoliquiritigenin. Carcinogenesis 1991, I 2:317-323.

65. Calliste CA, Le Bail JC, Trouillas P, Pouget C, Habrioux G, Chulia AJ, Duroux JL: Chalcones: structural requirements for antioxidant, estrogenic and antiproliferative activities. Anticancer Res 200I, $21: 3949-3956$

66. Liu M, Wilairat P, Croft SL, Tan AL, Go ML: Structure-activity relationships of antileishmanial and antimalarial chalcones. Bioorg Med Chem 2003, I I:2729-2738.

67. Dominguez JN, Charris JE, Lobo G, Gamboa de DN, Moreno MM, Riggione F, Sanchez E, Olson J, Rosenthal PJ: Synthesis of quinolinyl chalcones and evaluation of their antimalarial activity. Eur J Med Chem 200I, 36:555-560.

68. Yarishkin OV, Ryu HW, Park JY, Yang MS, Hong SG, Park KH: Sulfonate chalcone as new class voltage-dependent $\mathrm{K}+$ channel blocker. Bioorg Med Chem Lett 2008, 18:137-140.

69. Khatib S, Nerya O, Musa R, Shmuel M, Tamir S, Vaya J: Chalcones as potent tyrosinase inhibitors: the importance of a 2,4-substituted resorcinol moiety. Bioorg Med Chem 2005, I3:433-44I.

70. Jez JM, Ferrer JL, Bowman ME, Austin MB, Schroder J, Dixon RA, Noel JP: Structure and mechanism of chalcone synthase-like polyketide synthases. Ind Microbiol Biotechnol 200I, 27:393-398.

71. Dhar DN: The Chemistry of Chalcones and Related Compounds New York: John Wiley and Sons; 198I. 
72. Noungoue-tchamo D, Barron D, Mariotte AM: Synthesis of 5'-(3,3Dimethylallyl)-4'-Methoxyethoxymethyl Resacetophenone and Improved Preparation of Broussochalcones A and B. Natural Product Research 1995, 7:73-80.

73. Iwata S, Nishino T, Inoue H, Nagata N, Satomi Y, Nishino H, Shibata $\mathrm{S}$ : Antitumorigenic activities of chalcones (II). Photo-isomerization of chalcones and the correlation with their biological activities. Biol Pharm Bull 1997, 20:1266-1270.

74. Xia Y, Yang ZY, Xia P, Bastow KF, Nakanishi Y, Lee KH: Antitumor agents. Part 202: novel 2'-amino chalcones: design, synthesis and biological evaluation. Bioorg Med Chem Lett 2000, 10:699-701.

75. LeBlanc R, Dickson J, Brown T, Stewart M, Pati HN, VanDerveer D Arman H, Harris J, Pennington W, Holt HL Jr, Lee M: Synthesis and cytotoxicity of epoxide and pyrazole analogs of the combretastatins. Bioorg Med Chem 2005, I 3:6025-6034.

76. Dimmock JR, Jha A, Zello GA, Allen TM, Santos CL, Balzarini J, De CE, Manavathu EK, Stables JP: Cytotoxic 4'-aminochalcones and related compounds. Pharmazie 2003, 58:227-232.

77. Liu X, Go ML: Antiproliferative activity of chalcones with basic functionalities. Bioorg Med Chem 2007, 1 5:7021-7034.

78. Fenwick GR, Lutomski J, Nieman C: Liquorice, Glycyrrhiza glabra L.--Composition, uses and analysis. Food Chemistry 1990, 38:119-143.

79. Wegener JW, Nawrath $\mathrm{H}$ : Cardiac effects of isoliquiritigenin. Eur J Pharmacol 1997, 326:37-44.

80. Kang DG, Lee AS, Mun YJ, Woo WH, Kim YC, Sohn EJ, Moon MK, Lee HS: Butein ameliorates renal concentrating ability in cisplatin-induced acute renal failure in rats. Biol Pharm Bull 2004 27:366-370.

8I. Bertl E, Becker H, Eicher T, Herhaus C, Kapadia G, Bartsch H, Gerhauser $C$ : Inhibition of endothelial cell functions by novel potential cancer chemopreventive agents. Biochem Biophys Res Commun 2004, 325:287-295.

82. Albini A, Dell'Eva R, Vene R, Ferrari N, Buhler DR, Noonan DM, Fassina G: Mechanisms of the antiangiogenic activity by the hop flavonoid xanthohumol: NF-kappaB and Akt as targets. FASEB J 2006, 20:527-529.

83. Dell'Eva R, Ambrosini C, Vannini N, Piaggio G, Albini A, Ferrari N: AKT/NF-kappaB inhibitor xanthohumol targets cell growth and angiogenesis in hematologic malignancies. Cancer 2007, I I 0:2007-201 I.

84. Nakadate T, Aizu E, Yamamoto S, Kato R: Effects of chalcone derivatives on lipoxygenase and cyclooxygenase activities of mouse epidermis. Prostaglandins 1985, 30:357-368.

85. Sogawa S, Nihro Y, Ueda H, Miki T, Matsumoto H, Satoh T: Protective effects of hydroxychalcones on free radical-induced cell damage. Biol Pharm Bull 1994, I 7:25I-256.

86. Won SJ, Liu CT, Tsao LT, Weng JR, Ko HH, Wang JP, Lin CN: Synthetic chalcones as potential anti-inflammatory and cance chemopreventive agents. Eur J Med Chem 2005, 40: I 03-II2.

87. Saxena HO, Faridi U, Kumar JK, Luqman S, Darokar MP, Shanker K, Chanotiya CS, Gupta MM, Negi AS: Synthesis of chalcone derivatives on steroidal framework and their anticancer activities. Steroids 2007, 72:892-900.

88. Rojas J, Paya M, Dominguez JN, Luisa FM: The synthesis and effect of fluorinated chalcone derivatives on nitric oxide production. Bioorg Med Chem Lett 2002, I 2: 195I-1954.

89. Nakamura C, Kawasaki N, Miyataka H, Jayachandran E, Kim IH, Kirk KL, Taguchi T, Takeuchi Y, Hori H, Satoh T: Synthesis and biological activities of fluorinated chalcone derivatives. Bioorg Med Chem 2002, 10:699-706.

90. Dimmock JR, Kandepu NM, Hetherington M, Quail JW, Pugazhenthi U, Sudom AM, Chamankhah M, Rose P, Pass E, Allen TM, Halleran S, Szydlowski J, Mutus B, Tannous M, Manavathu EK, Myers TG, De CE, Balzarini J: Cytotoxic activities of Mannich bases of chalcones and related compounds. I Med Chem 1998, 4I:1014-1026.

91. Zhang Y, Guo X, Lin ET, Benet LZ: In vitro biotransformation of a novel antimalarial cysteine protease inhibitor in human liver microsomes. Pharmacology 1999, 58:147-159.

92. Prabhakar B, Laxma Reddy K, Lingaiah K: Synthesis, thermal, spectral and magnetic studies of complexes of $\mathrm{Co}$ (II), $\mathrm{Ni}$ (II), $\mathrm{Cu}$ (II), $\mathrm{Ru}$ (II), Pd(II) and Pt(II) with 2,3-disubstituted quinazolin-(3H)-4-ones. J Chem Sci 1989, I0 I: I 2 I-132.

93. Sarkar FH, Li Y: NF-kappaB: a potential target for cancer chemoprevention and therapy. Front Biosci 2008, 13:2950-2959.
94. Sarkar FH, Li Y, Wang Z, Kong D: NF-kappaB signaling pathway and its therapeutic implications in human diseases. Int Rev Immunol 2008, 27:293-319.
Publish with Biomed Central and every scientist can read your work free of charge

"BioMed Central will be the most significant development for disseminating the results of biomedical research in our lifetime. "

Sir Paul Nurse, Cancer Research UK

Your research papers will be:

- available free of charge to the entire biomedical community

- peer reviewed and published immediately upon acceptance

- cited in PubMed and archived on PubMed Central

- yours - you keep the copyright

Submit your manuscript here:

http://www.biomedcentral.com/info/publishing_adv.asp 